\title{
Analisis Prioritas Rehabilitasi Bendung:Studi Kasus Bendung Cokrobedog, Gamping, Pendowo dan Pijenan di Kali Bedog
}

\author{
(Priority Analisys For Weir Rehabilitation: A Case Study on Cokrobedog, Gamping, Pendowo, and Pijenan \\ Weirs in Kali Bedog)
}

\section{NANDA MELYADI PUTRI}

\begin{abstract}
The government provided Special Allocation Budget via APBD for rehabilitation activities in order to increase the function and physical condition of the weirs. The rehabilitation performances must be run stage by stage due to the limitation of allocation budget, however, it would be continual. Hence the analysis of rehabilitation priority was needed. The case study of this research was the determination of rehabilitation priority towards the weirs of Cokrobedog, Gamping, Pendowo, and Pijenan. These four weirs were at Kali Bedog, Daerah Istimewa Yogyakarta.The method used for priority analysis in this research was Multi Attribute Decision Making method (MADM), consisted of AHP, ELECTRE, SAW, TOPSIS, and WP. The criterias used were the infrastructure conditions, the availability of water, and the command areas by the percentage weighting of assessment criteria at 57, 29 and 14. The damage percentage of Gamping was $44.66 \%$, ranked as serious damage. The damage percentage of Cokrobedog, Pendowo and Pijenan for each of it was $36.11 \%, 33.57 \%$ and $30.30 \%$, ranked as average damage. The order of priority rehabilitation of dams tend not begin with the largest command area. TOPSIS method is a method most appropriate MADM applied in the prioritization of rehabilitation because it has a significantly different end value.
\end{abstract}

Keywords: The damage of weirs, Rehabilitation priority of weirs, MADM

\section{PENDAHULUAN}

Pertanian merupakan sektor yang penting dalam pembangunan suatu daerah karena sangat berperan dalam penyediaan kebutuhan pokok dan juga merupakan mata pencaharian penduduk di perdesaan. Pemenuhan kebutuhan akan pangan dan aktivitas sehari-hari seiring dengan laju pertumbuhan penduduk menyebabkan kebutuhan air terus meningkat. Sistem irigasi merupakan salah satu komponen pendukung keberhasilan pembangunan di sektor pertanian. Pengembangan dan pengelolaan sistem irigasi membutuhkan infrastruktur yang salah satunya adalah bendung. Infrastruktur yang baik akan menunjang peningkatan produksi bahan pangan, meningkatkan kesejahteraan masyarakat serta mengoptimalkan pemanfaatan sumber daya air. Permasalahan yang terjadi sekarang adalah banyak area sawah yang masih kekurangan air. Salah satu penyebabnya adalah kerusakan yang terjadi pada bangunan irigasi (bendung) baik dari segi infrastruktur maupun segi fungsional. Rehabilitasi bangunan irigasi dinilai merupakan langkah yang mutlak untuk dilakukan segera oleh pemerintah saat ini, khususnya untuk mendukung ketahanan pangan.

Pemerintah melalui APBN menyediakan Dana Alokasi Khusus (DAK) yang dapat dimanfaatkan untuk kegiatan rehabilitasi dengan tujuan untuk meningkatkan fungsi dan kondisi fisik bangunan irigasi. Alokasi DAK yang terbatas mengakibatkan pelaksanaan rehabilitasi harus dilakukan secara bertahap tetapi berkelanjutan, sehingga diperlukan analisis prioritas rehabilitasi.

\section{Jaringan Irigasi}

Jaringan irigasi adalah saluran, bangunan utama, dan bangunan pelengkapnya yang merupakan satu kesatuan dan diperlukan untuk pengaturan air irigasi. Operasi dan pemeliharaan jaringan irigasi merupakan suatu 
kegiatan pengaturan air dan jaringan irigasi yang meliputi penyediaan, pembagian, pemberian, penggunaan, dan pembuangannya, termasuk usaha mempertahankan kondisi jaringun irigasi agar tetap berfungsi dengan baik. Pengelolaan jaringan irigasi adalah kegiatan yang meliputi operasi, pemeliharan (OP), dan rehabilitasi jaringan irigasi di daerah irigasi (Peraturan Pemerintah No.23, 1982). Pengelolaan sistem jaringan irigasi akan berhasil apabila didukung dengan beberapa faktor seperti irigator (juru pintu) sebagai pengatur pemberian air secara tepat jumlah dan tepat waktu, perangkat lunak dan keras (peraturan perundangan dan bangunan air sebagai pengatur dan pengukur), dan aktivitas (kegiatan pengelolaan di saluran dan di lahan pertanian (Nurrochmad, 1998). Rehabilitasi jaringan irigasi merupakan kegiatan perbaikan jaringan irigasi guna mengembalikan fungsi dan pelayanan irigasi seperti semula (Permen PU No.17/PRT/M/2015). Luas area, ketersediaan air, dan kondisi fisik bangunan irigasi merupakan parameter penilaian yang digunakan dalam menyusun prioritas rehabilitasi bangunan irigasi.

Aprilina (2013) mengemukakan bahwa semakin luas area daerah irigasi maka memiliki prioritas rehabilitasi yang semakin besar, sebaliknya semakin kecil luas area daerah irigasi maka semakin rendah pula prioritas rehabilitasi yang diperoleh. Ketersediaan air tidak berpengaruh besar pada penentuan prioritas rehabilitasi (Aprilina, 2013).

Kondisi prasarana jaringan irigasi menurut Nurrochmad (2008) ada 4 (empat) golongan, yaitu:

a. kondisi rusak ringan apabila kerusakan fisik pada bangunan irigasi tidak mengganggu proses penyadapan, pembagian dan pemberian air irigasi hingga ke petak tersier,

b. kondisi rusak sedang, apabila kerusakan fisik pada bangunan menyebabkan air irigasi tidak sesuai dengan permintaan,

c. kondisi rusak berat, apabila kerusakan fisik pada bangunan menyebabkan air irigasi tidak dapat diterima hingga daerah layanan,

d. kondisi bagus, apabila tidak terdapat kerusakan fisik pada bangunan sehingga tidak menimbulkan gangguan dalam pendistribusian air.

Kondisi fisik infrastruktur menunjukkan keadaan fisik infrastruktur yang sesuai dengan desain/rencana. Kerusakan merupakan perubahan kondisi fisik dari desain aset akibat usia, iklim dan kesalahan operasi infrastruktur. Semakin lama kerusakan aset akan semakin meningkat. Permen PU Nomor 12/PRT/M/2015 menilai persentase kerusakan aset ke dalam empat kriteria kerusakan, yaitu:

a. kondisi baik, jika tingkat kerusakan < $10 \%$ dari kondisi awal bangunan/saluran,

b. kondisi rusak ringan, jika tingkat kerusakan $10-20 \%$ dari kondisi awal bangunan/saluran,

c. kondisi rusak sedang, jika tingkat kerusakan $21-40 \%$ dari kondisi awal bangunan/saluran,

d. kondisi rusak berat, jika tingkat kerusakan > $40 \%$ dari kondisi awal bangunan/saluran.

Kriteria Penilaian Kondisi Fungsional, meliputi:

a. fungsi baik, jika secara nyata masih berfungsi sesuai saat dirancang dan dibangun dengan kapasitas untuk mengalirkan secara aman, memiliki kemampuan penuh dalam operasinya,

b. kurang berfungsi, jika adanya penurunan fungsi dalam pengaliran air secara hidrolik yang mungkin disebabkan karena kurang nya pemeliharaan dan adanya endapan (lumpur),

c. sangat kurang berfungsi, jika fungsi yang ditunjukan dengan adanya perubahan kondisi fisik bangunan yang akibatnya akan mengurangi fungsi bangunan secara serius dan memerlukan perhatian dan perbaikan segera.,

d. tidak berfungsi, jika aset dengan kriteria ini sudah tidak dapat berfungsi secara total, sehingga memungkinkan berpengaruh terhadap kinerja layanan irigasi.

\section{METODOLOGI PENELITIAN}

Analisis dalam penentuan prioritas rehabilitasi meliputi analisis kondisi prasarana, analisis ketersediaan air, dan analisis prioritas rehabilitasi. Multi Attribute Decision Making (MADM) merupakan salah satu metode yang 
digunakan untuk melakukan analisis terhadap beberapa alternatif dalam jumlah yang terbatas (Kusumadewi dkk, 2006).

\section{Kondisi prasarana}

Ciri-ciri dari kondisi fisik dan fungsi prasarana yang dikembangkan berdasarkan Permen PU No.12/PRT/M/2015 dapat dilihat pada Tabel 2 dan Tabel 3.

\section{Lokasi penelitian}

TABEL 1. Lokasi Penelitian

\begin{tabular}{llcccc}
\hline \multirow{2}{*}{ No } & \multirow{2}{*}{ Bendung } & \multicolumn{2}{c}{ Luas (ha) } & \multicolumn{2}{c}{ Koordinat Lokasi } \\
\cline { 2 - 5 } 1 & Cokrobedog & 194 & 188 & $7^{\circ} 46^{\prime} 49^{\prime \prime}$ & $110^{\circ} 19^{\prime} 36.4^{\prime \prime}$ \\
2 & Gamping & 532 & 530 & $7^{\circ} 47^{\prime} 37^{\prime \prime}$ & $110^{\circ} 19^{\prime} 36.7^{\prime \prime}$ \\
3 & Pendowo & 1251 & 1112 & $7^{\circ} 51^{\prime} 3,82^{\prime \prime}$ & $110^{\circ} 17^{\prime} 47,8^{\prime \prime}$ \\
& & & & & \\
4 & Pijenan & 2563 & 2142 & $7^{\circ} 53^{\prime} 94.3^{\prime \prime}$ & $110^{\circ} 17^{\prime} 72.5^{\prime \prime}$
\end{tabular}

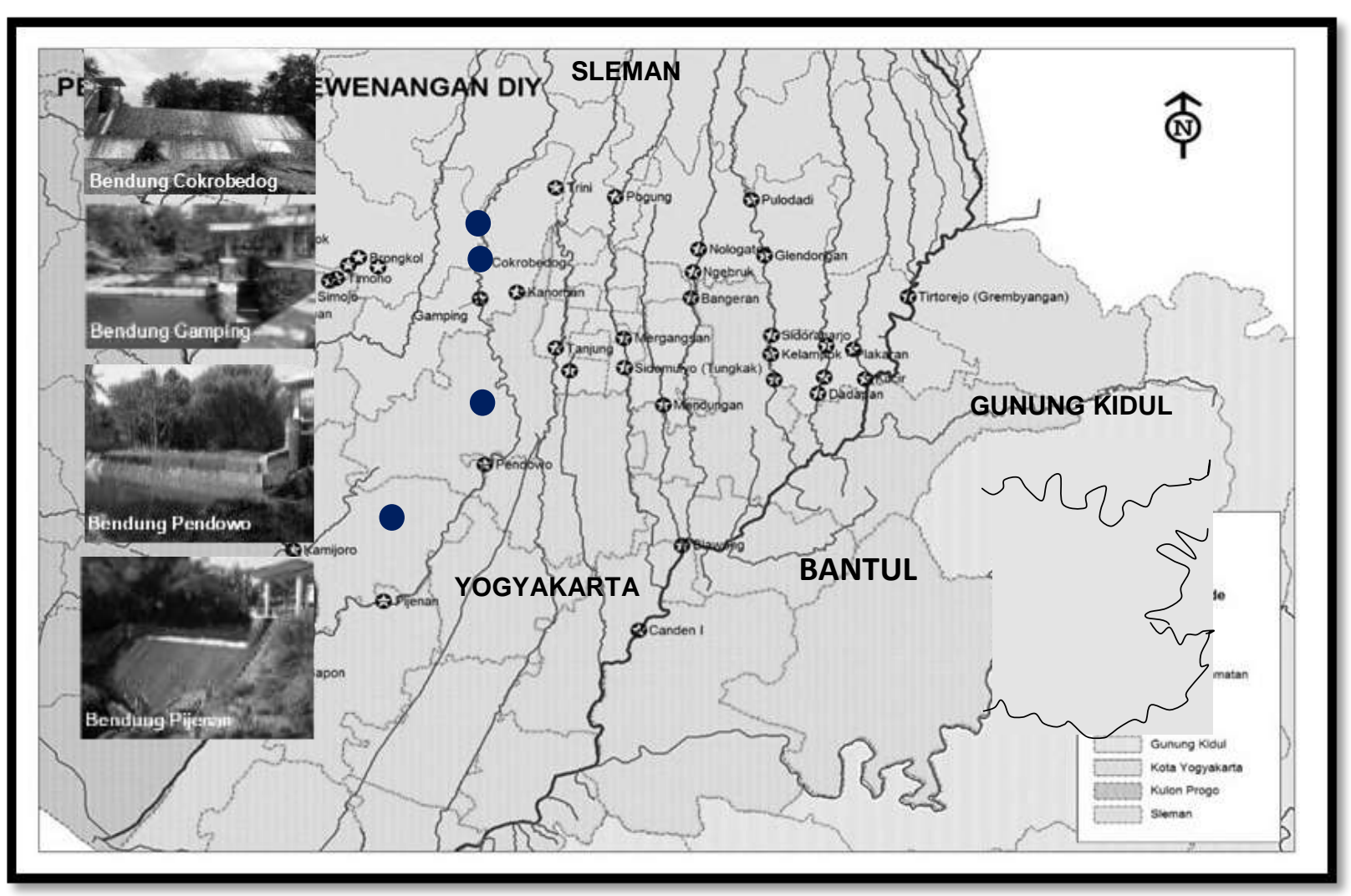

GAMBAR 1. Lokasi Penelitian

Provinsi Daerah Istimewa Yogyakarta terletak pada $7^{\circ} 3^{\prime}-8^{\circ} 12^{\prime}$ lintang selatan dan $110^{\circ} 00^{\prime}-$ $110^{\circ} 50^{\prime}$ bujur timur. Lokasi penelitian ini dilaksanakan pada 4 (empat) bendung di Kali Bedog yang berada dalam kewenangan provinsi Daerah Istimewa Yogyakarta. Lokasi penelitian dapat dilihat pada Tabel 1 dan Gambar 1 berikut: 
TABEL 2. Ciri-Ciri Kriteria Kondisi Fisik

\begin{tabular}{|c|c|}
\hline Kriteria & Kondisi Fisik \\
\hline Baik & $\begin{array}{l}\text { 1. Bentuk fisik bangunan terlihat utuh tidak ada kerusakan. } \\
\text { 2. Pintu tidak ada yang bocor. }\end{array}$ \\
\hline Tingkat & 3. Mistar ukur terlihat jelas. \\
\hline Kerusakan $<10 \%$ & $\begin{array}{l}\text { 4. Tidak ada gerusan pada lantai dihilir bangunan. } \\
\text { 5. Terlihat agak kotor (sampah/tanamana bersemak dll). }\end{array}$ \\
\hline Rusak Ringan & $\begin{array}{l}\text { 1. Bentuk fisik bangunan tampak ada perubahan. } \\
\text { 2. } \quad \text { Plesteran/siar ada beberapa yang mengelupas. }\end{array}$ \\
\hline Tingkat & 3. Terlihat retakan rambut tidak struktur. \\
\hline Kerusakan & 4. Pintu ada bocoran kecil. \\
\hline $10-20 \%$ & $\begin{array}{l}\text { 5. Operasi pintu berat kurang pelumas/berkarat. } \\
\text { 6. Mistar ukur hilang sebagian. } \\
\text { 7. Ada gerusan kecil lantai hilir bangunan. }\end{array}$ \\
\hline Rusak Sedang & $\begin{array}{l}\text { 1. Bentuk fisik bangunan tampak ada perubahan } \\
\text { a. Plesteran/siar ada sebagian yang mengelupas }\end{array}$ \\
\hline Tingkat & b. Terlihat retakan struktur/pecah \\
\hline Kerusakan & 2. Pintu ada bocoran cukup besar. \\
\hline \multirow[t]{4}{*}{$21-40 \%$} & 3. Komponen alat pemutar hilang/rusak. \\
\hline & 4. Operasi pintu berat kurang pelumas/berkarat/macet. \\
\hline & 5. Mistar ukur hilang. \\
\hline & $\begin{array}{l}\text { 6. Ada gerusan cukup dalam lantai dihilir bangunan } \\
\text { berdampak kerusakan lantai. }\end{array}$ \\
\hline Rusak Berat & $\begin{array}{l}\text { 1. Bentuk fisik bangunan tampak ada perubahan serius. } \\
\text { a. Plesteran/siar ada sebagian besar mengelupas. }\end{array}$ \\
\hline Tingkat & b. Terlihat struktur pecah-pecah. \\
\hline \multirow[t]{6}{*}{ Kerusakan $>40 \%$} & c. Stabilitas terganggu. \\
\hline & 2. Pintu ada bocoran besar. \\
\hline & 3. Ulir pintu bengkok/daun pintu rusak keropos. \\
\hline & 4. Pintu tidak dapat dioperasikan sama sekali. \\
\hline & 5. Mistar ukur hilang. \\
\hline & $\begin{array}{l}\text { 6. Ada gerusan cukup dalam lantai dihilir bangunan } \\
\text { berdampak kerusakan lantai. }\end{array}$ \\
\hline
\end{tabular}

TABEL 3. Ciri-Ciri Kriteria Kondisi Fungsional

\begin{tabular}{cll}
\hline Kriteria & & \multicolumn{1}{c}{ Kondisi Fungsional } \\
\hline \multirow{3}{*}{ Baik } & 1. & Pintu air dapat dioperasikan sesuai prosedur. \\
& 2. & Dapat mengalirkan debit air rencana. \\
& 3. & Bangunan ukur dapat untuk mengukur dengan baik. \\
4. & Bangunan dapat digunakan dengan baik. \\
\hline \multirow{3}{*}{ Kurang } & 1. & Pintu air dapat dioprasikan sesuai prosedur. \\
& 2. & Dapat mengalirkan debit air rencana. \\
& 3. & Bangunan ukur kurang dapat mengukur dengan baik. \\
& 4. & Bangunan dapat digunakan dengan baik. \\
& 1. & Pintu air tidak dapat dioperasikan sesuai prosedur. \\
& 2. & Kurang dapat mengalirkan debit rencana. \\
& 3. & Bangunan ukur tidak dapat untuk mengukur dengan baik. \\
& 4. & Bangunan kurang dapat digunakan dengan baik. \\
\hline \multirow{3}{*}{ Tidak Berfungsi } & 1. & Pintu air tidak dapat dioperasikan. \\
& 2. & Tidak dapat mengalirkan debit rencana. \\
& 3. & Bangunan ukur tidak dapat digunakan untuk mengukur. \\
& 4. & Bangunan tidak dapat digunakan dengan baik. \\
\hline
\end{tabular}

Nilai kondisi fisik dan fungsi tiap bendung merupakan nilai total dari keseluruhan tiap infrastruktu, yang didapatkan dari perkalian antara nilai tiap prasarana dengan masing- masing nilai bobot dari kondisi prasarana. Bobot kondisi prasarana dan gambar jenis prasarana yang dinilai dapat dilihat pada Tabel 4 dan Gambar 2. 
TABel 4. Jenis dan Bobot Kondisi Prasana

\begin{tabular}{cllc}
\hline No & & Penilaian & Bobot (\%) \\
\hline 1 & & Tubuh Bendung & 20,0 \\
2 & & Kolam Olak & 6,5 \\
3 & & Lantai Hilir & 6,5 \\
4 & Bendung & Bangunan Intake & 4,0 \\
5 & & Pintu Pembilas & 4,0 \\
6 & & Sayap Kaki Hulu & 3,0 \\
7 & & Sayap Kaki Hilir & 3,0 \\
8 & & Peilschaal & 3,0 \\
\hline 9 & & Bagian Dalam Kantong Lumpur & 3,5 \\
10 & & Bagian Luar Kantong Lumpur & 3,5 \\
11 & & Dasar Kantong Lumpur & 3,0 \\
12 & & Saluran Penguras & 3,5 \\
13 & & Dasar Saluran Penguras & 3,0 \\
14 & Kantong & Talud & 3,5 \\
15 & Lumpur & Bangunan Ukur Debit & 4,0 \\
16 & & Peilschaal & 3,0 \\
17 & & Pintu & 3,5 \\
18 & & Ulir & 3,0 \\
19 & & Setang Ulir & 3,0 \\
20 & & Sedimentasi/Rumput/Sampah & 3,5 \\
\hline 21 & & Jalan Inspeksi/Jembatan & 2,0 \\
22 & Bangunan & Trashrack & 1,5 \\
23 & Bangunan Pelindung/Talud & 2,5 \\
24 & & Papan Nama/Papan Eksploitasi & 2,0 \\
25 & & Rumah Pintu & 2,0 \\
\hline
\end{tabular}

*Penilaian pada nomor 20 bukan pada infrastruktur, tetapi dianggap penting karena mempengaruhi penilaian prioritas rehabilitasi bendung.

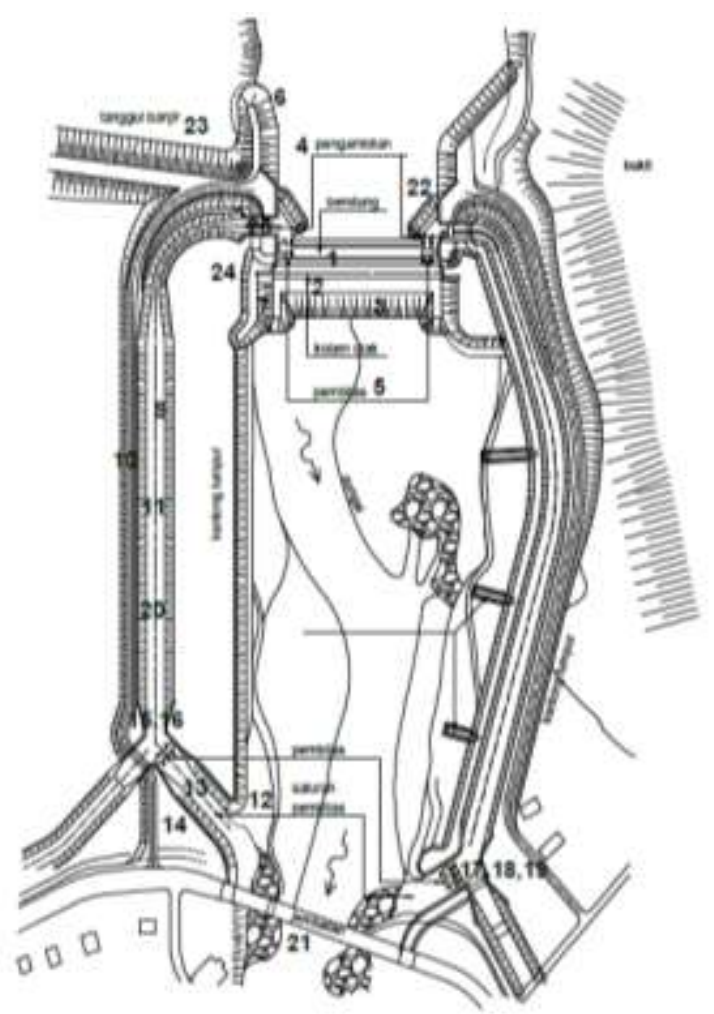

GAMBAR 2. Jenis Prasarana 


\section{Bobot kriteria prioritas rehabilitasi}

Bobot yang digunakan pada tiap kriteria berbeda-beda. Bobot semula terbagi untuk enam kriteria, yaitu bobot kondisi prasarana 40 , bobot ketersediaan air 20, bobot luas area 10 , bobot intensitas tanam 10, bobot produksi padi 10, dan bobot biaya OP 10 (permen PU No. 39/PRT/M/2006). Kriteria yang digunakan dalam penelitian ini sudah mengacu pada permen PU No. 03/PRT/M/2015, yaitu kondisi prasarana, ketersediaan air, dan luas area irigasi. Bobot kriteria didapatkan dari pembagian antara bobot semula dengan total ketiga bobot kriteria.

TABel 5. Kriteria dan Bobot Prioritas Rehabilitasi

\begin{tabular}{ll}
\hline Kriteria Prioritas Rehabilitasi & Bobot (\%) \\
\hline Kondisi Prasarana & 57 \\
Ketersediaan Air & 29 \\
Luas Area Irigasi & 14 \\
\hline
\end{tabular}

\section{HASIL DAN PEMBAHASAN}

\section{Penilaian kondisi prasarana}

Penilaian kondisi prasarana bendung dibagi menjadi 4 (empat) berdasarkan tingkat kerusakan fisik dan fungsi dari prasarana. Nilai kondisi yang digunakan merupakan nilai tengah dari rentang kerusakan prasarana.

TABEL 6. Nilai Kondisi Fisik dan Fungsi Prasarana

\begin{tabular}{llll}
\multicolumn{3}{c}{ TABEL 6. Nilai Kondisi Fisik dan Fungsi Prasarana } \\
\hline $\begin{array}{l}\text { Kondisi Fisik } \\
\text { Bendung }\end{array}$ & Nilai & $\begin{array}{l}\text { Kondisi } \\
\text { Fungsi } \\
\end{array}$ & Nilai \\
& \multicolumn{3}{c}{ Bendung } \\
\hline Baik & 0,045 & Baik & 0,1 \\
Rusak Ringan & 0,15 & Kurang & 0,3 \\
Rusak Sedang & 0,305 & Rusak & 0,6 \\
Rusak Berat & 0,705 & Tidak & 0,9 \\
& \multicolumn{3}{c}{ Berfungsi } \\
\hline
\end{tabular}

TABel 7. Persentase Kondisi Prasana

\begin{tabular}{lllll}
\hline Penilaian & Cokrobedog & Gamping & Pendowo & Pijenan \\
\hline Bendung & 0,1483 & 0,1846 & 0,1054 & 0,1725 \\
$\begin{array}{l}\text { Kantong } \\
\text { Lumpur }\end{array}$ & 0,1530 & 0,1637 & 0,1341 & 0,1053 \\
$\begin{array}{l}\text { Bangunan } \\
\text { Lainnya }\end{array}$ & 0,0597 & 0,0983 & 0,0962 & 0,0252 \\
$\begin{array}{l}\text { Kondisi } \\
\text { Prasarana }\end{array}$ & 36,11 & 44,66 & 33,57 & 30,30 \\
$(\%)$ & & & & \\
\hline
\end{tabular}

Nilai kondisi kerusakan bendung Gamping sebesar $44,66 \%$ tergolong dalam kondisi rusak berat sehingga perlu segera direhabilitasi. Nilai kondisi kerusakan bendung Cokrobedog, Pendowo dan Pijenan masing-masing sebesar $36,11 \%$, 33,57\% dan 30,30\% (Tabel 7) tergolong dalam kondisi rusak sedang sehingga perlu dilakukan perbaikan atau penggatian serta rehabilitasi ringan. Kerusakan pada bendung-bendung tersebut harus segera direhabilitasi atau dilakukan perbaikan untuk mencegah kerusakan yang lebih buruk agar prasarana dapat berfungsi secara maksimal.

\section{Ketersediaan air dan luas areal irigasi}

Jumlah bulan ketersediaan air dalam bendung irigasi tidak mencapai 12 bulan apabila kebutuhan air dalam suatu periode lebih besar jika dibandingkan dengan air yang tersedia di sumbernya. Hal itu dikarenakan adanya daerah irigasi yang tidak terlayani.

Area beririgasi adalah area pertanian yang telah ditetapkan menjadi area irigasi dan mendapatkan pelayanan air dari jaringan irigasi. Data alih fungsi area dalam penelitian ini diperoleh dari instansi terkait. Ketersediaan air (bulan) dan data luas area irigasi dapat dilihat pada Tabel 8.

TABEL 8. Ketersediaan Air dan Luas Area Irigasi

\begin{tabular}{lcll}
\hline Bendung & $\begin{array}{l}\text { Durasi } \\
\text { Ketersediaan } \\
\text { Air (bulan) }\end{array}$ & $\begin{array}{l}\text { Luas } \\
\text { Baku } \\
\text { (ha) }\end{array}$ & $\begin{array}{l}\text { Luas Area } \\
\text { Irigasi (ha) }\end{array}$ \\
\hline Cokrobedog & 12 & 194 & 188 \\
Gamping & 11 & 532 & 530 \\
Pendowo & 10 & 1251 & 1112 \\
Pijenan & 11 & 2563 & 2142 \\
\hline
\end{tabular}

\section{Prioritas rehabilitasi MADM}

Metode-metode yang biasa digunakan dalam metode MADM, yaitu Analytical Hierarcy Process (AHP), Elimination and Choice Translation Reality (ELECTRE), Simple Additive Weighting Method (SAW), Technique for Order Preference by Similarity to Ideal Solution (TOPSIS), dan Weighted Product (WP).

TABEL 9. Nilai Prioritas Rehabilitasi Metode AHP

$\begin{array}{ccc}\text { Bendung } & \text { Nilai Preferensi } & \text { Urutan } \\ \text { Prioritas Rehabilitasi } & \text { Prioritas }\end{array}$

\begin{tabular}{lll}
\hline Cokrobedog & 0,2349 & 4 \\
Gamping & $\mathbf{0 , 2 6 8 3}$ & $\mathbf{1}$ \\
Pendowo & 0,2503 & 3 \\
Pijenan & 0,2665 & 2 \\
\hline
\end{tabular}


TABEL 10. Nilai Prioritas Rehabilitasi ELECTRE

\begin{tabular}{lcc}
\hline \multicolumn{1}{c}{ Alternatif Bendung } & Nilai & Prioritas \\
\hline Cokrobedog & 0,1134 & 4 \\
Gamping & $\mathbf{0 , 1 2 8 2}$ & $\mathbf{1}$ \\
Pendowo & 0,1181 & 3 \\
Pijenan & 0,1229 & 2 \\
\hline
\end{tabular}

TABEL 11. Nilai Prioritas Rehabilitasi SAW

\begin{tabular}{lcc}
\hline \multicolumn{1}{c}{ Bendung } & $\begin{array}{c}\text { Nilai Prioritas } \\
\text { Rehabilitasi }\end{array}$ & Urutan Prioritas \\
\hline Cokrobedog & 76,3137 & 4 \\
Gamping & $\mathbf{8 4 , 6 3 1 1}$ & $\mathbf{1}$ \\
Pendowo & 76,7028 & 3 \\
Pijenan & 76,8346 & 2 \\
\hline
\end{tabular}

TABEL 12. Nilai Prioritas Rehabilitasi TOPSIS

\begin{tabular}{lcc}
\hline Kriteria & $\begin{array}{c}\text { Nilai Prioritas } \\
\text { Rehabilitasi }\end{array}$ & Urutan Prioritas \\
\hline Cokrobedog & 0,2901 & 4 \\
Gamping & $\mathbf{0 , 5 4 4 8}$ & $\mathbf{1}$ \\
Pendowo & 0,3662 & 3 \\
Pijenan & 0,4893 & 2 \\
\hline
\end{tabular}

TABEL 13. Nilai Prioritas Rehabilitasi WP

\begin{tabular}{llll}
\hline Kriteria & Si & $\begin{array}{l}\text { Nilai } \\
\text { Rehabilitasi }\end{array}$ & $\begin{array}{l}\text { Prioritasn } \\
\text { Prioritas }\end{array}$ \\
\hline Cokrobedog & 2,3945 & 0,2153 & 4 \\
Gamping & 2,9637 & $\mathbf{0 , 2 6 6 5}$ & $\mathbf{1}$ \\
Pendowo & 2,8726 & 0,2583 & 3 \\
Pijenan & 2,8886 & 0,2598 & 2 \\
\hline
\end{tabular}

Analisis prioritas rehabilitasi dengan menggunakan metode MADM menunjukan bahwa bendung yang selalu masuk dalam prioritas rehabilitasi teratas adalah bendung Gamping dan bendung Pijenan. Bendung Gamping merupakan bendung dengan luas area irigasi diatas 500 ha dan kondisi kerusakan prasarana diatas $40 \%$ (tergolong kedalam rusak berat). Bendung Pijenan merupakan bendung dengan luas area irigasi diatas 2000 ha. Bendung Pendowo dan bendung Cokrobedog merupakan bendung yang selalu mendapatkan urutan prioritas rehabilitasi terbawah. Luas area irigasi bendung Pendowo diatas 1000 ha dan ketersediaan air yang tercukupi selama 11 bulan. Luas area irigasi bendung Cokrobedog dibawah 500 ha, dan ketersediaan air pada bendung Cokrobedog terpenuhi semua bulan (12 bulan). Rekapitulasi nilai kriteria tiap bendung selengkapnya dapat dilihat pada Tabel 19. Luas area irigasi yang semakin luas memiliki prioritas rehabilitasi yang semakin besar, sebaliknya semakin kecil luas area irigasi maka semakin rendah pula prioritas rehabilitasi yang diperoleh. Kondisi kerusakan bendung Cokrobedog lebih besar jika dibandingkan dengan bendung Pendowo dan bendung Pijenan, ketersediaan air juga tepenuhi selama 12 bulan, akan tetapi urutan prioritas rehabilitas bendung Cokrobedog selalu terbawah. Hal itu dikarenakan luas area irigasi bendung Cokrobedog lebih kecil diantara bendung lainnya yaitu 188 ha (dibawah 500 ha). Kondisi tersebut menjelaskan bahwa urutan prioritas rehabilitasi cenderung dimulai dari luas area irigasi terbesar. Bendung Pijenan dan bendung Pendowo memiliki luas area irigasi yang lebih besar jika dibandingkan dengan bendung Gamping yang mempunyai urutan teratas. Hal ini menunjukkan ketidak konsistenan kelima metode yang digunakan. Kriteria yang berpengaruh dalam penelitian ini adalah kondisi prasarana dan luas area. Ketersediaan air pada hasil analisis tidak berpengaruh besar dalam penentuan prioritas rehabilitasi.

Hasil analisis yang cukup berbeda ditunjukkan oleh metode TOPSIS. Penilaian prioritas dengan metode TOPSIS dinilai yang paling sesuai digunakan dalam penentuan prioritas rehabilitasi bendung di Kali Bedog. Hasil dari keempat metode MADM yang lain tidak memberikan nilai yang beda nyata, sehingga sulit untuk digunakan dalam penentuan prioritas rehabilitasi bendung. Urutan prioritas rehabilitasi dari yang teratas adalah bendung Gamping, bendung Pijenan, bendung Pendowo, dan bendung Cokrobedog.

\section{KESIMPULAN}

1. Kondisi kerusakan bendung Gamping sebesar $44,66 \%$ tergolong dalam kondisi rusak berat sehingga perlu segera direhabilitasi. Kondisi kerusakan bendung Cokrobedog, Pendowo dan Pijenan masingmasing sebesar $36,11 \%, 33,57 \%$ dan $30,30 \%$ tergolong dalam kondisi rusak sedang sehingga perlu dilakukan perbaikan atau penggatian serta rehabilitasi ringan.

2. Urutan prioritas rehabilitasi cenderung tidak dimulai dari luas area irigasi terbesar, yaitu bendung Gamping, bendung Pijenan, bendung Pendowo, dan bendung Cokrobedog.

3. Metode TOPSIS merupakan metode yang paling sesuai dterapkan pada penentuan 
prioritas rehabilitasi karena memberikan nilai prioritas yang nyata dibandingkan dengan metode Multi Attribut Decision Making (MADM) lainnya.

\section{DAFTAR PUSTAKA}

BNPB, (2008). Peraturan Badan Nasional Penanggulangan Bencana No. 11 Tahun 2008 tentang Pedoman Rehabilitasi dan rekonstruksi Pasca Bencana, Jakarta.

Departemen Pekerjaan Umum, (2015). Peraturan Menteri PUPR No. 03/PRT/M/2015 Tentang Petunjuk Teknis Penggunaan Dana Alokasi Khusus Bidang Infrastruktur. Direktorat Jenderal Sumber Daya Air, Jakarta.

Departemen Pekerjaan Umum, (2015). Peraturan Menteri PUPR No. 12/PRT/M/2015 Tentang Eksploitasi dan Pemeliharaan Jaringan irigasi. Direktorat Jenderal Sumber Daya Air, Jakarta.

Departemen Pekerjaan Umum, (2015). Peraturan Menteri PUPR No. 23/PRT/M/2015 Tentang Pengelolaan Aset irigasi. Direktorat Jenderal Sumber Daya Air, Jakarta.

Direktorat Jenderal Sumber Daya Air. (2011). Standar Perencanaan Irigasi KP 01. Direktorat Jenderal Sumber Daya Air, Jakarta.

Direktorat Jenderal Sumber Daya Air. (2011). Standar Perencanaan Irigasi KP 02.
Direktorat Jenderal Sumber Daya Air, Jakarta.

Fatchan Nurrochmad, (2008). Analysis of Rehabilitation Priority of Irrigation Infrastructure, Dinamika Teknik Sipil Vol.8, No.1, Januari 2008, Yogyakarta.

Pemerintah Republik Indonesia, (1974). Undang-Undang Republik Indonesia Nomor 11 Tentang Pengairan, Jakarta.

Pemerintah Republik Indonesia, (1982). Peraturan Pemerintah Republik Indonesia Nomor 22 Tentang Tata Pengaturan Air, Jakarta.

Sri Kusumadewi, Hartati, S., Harjoko, A., Wardoyo, R., (2006). Fuzzy Multi Attribute Decision Making (Fuzzy $M A D M)$, Graha Ilmu, Yogyakarta.

Yunita Aprilina, (2013). Analisis Prioritas Operasi dan pemeliharaan serta Rehabilitasi Daerah Irigasi (Studi Kasus 8 daerah Irigasi Di Daerah Istimewa Yogyakarta), Tesis, Universitas Gadjah Mada, Yogyakarta.

PENUlis:

Nanda Melyadi Putri

Program Studi Teknik Sipil, Fakultas Sains dan Teknologi, Universitas Teknologi Yogyakarta, Kota Yogyakarta.

Email: nanda.putri@staff.uty.ac.id 